\title{
PENGARUH RASIO PROFITABILITAS PADA INDUSTRI PERBANKAN YANG GO PUBLIC TERHADAP HARGA SAHAM DI BURSA EFEK INDONESIA
}

\author{
SYUAIB \\ MUSLIMIN \\ HARNIDA WAHYUNI ADDA \\ Jurusan Manajemen, Fakultas Ekonomi, Universitas Tadulako \\ sandhyson@gmail.com
}

\begin{abstract}
This research aims to determine and analyze the influence of Return On Assets (ROA), Return On Equity (ROE), and Net Profit Margin (NPM) on stock price, both simultaneously and partially. The sample of this research consists of 30 banks listed on Indonesia Stock Exchange (IDX). Method of analysis is multiple linear regressions. The results show that ROA, ROE, and NPM simultaneously have significant influence on stock prices in Indonesia Stock Exchange. Partially, ROA, ROE, and NPM have significant influence on stock prices in Indonesia Stock Exchange, while the influence of $R O E$ on stock prices is negative. Coefficient determination indicates adjusted R-square of 0.529, which means that $52.90 \%$ of stock prices affected by ROA, ROE, and NPM, and $47.10 \%$ of stock prices affected by other variables that are not studied.
\end{abstract}

Keywords: profitability ratio, go public, banking industry, stock price, and Indonesia Stock Exchange

\begin{abstract}
Abstrak
Penelitian ini bertujuan untuk mengetahui dan menganalisis pengaruh return on asset (ROA), return on equity (ROE), dan margin laba bersih terhadap harga saham secara simultan dan parsial. Sampel penelitian ini terdiri dari 30 bank yang terdaftar di Bursa Efek Indonesia (BEI). Metode analisis yang digunakan adalah regresi linier berganda. Hasil penelitian menunjukkan bahwa return on asset, return on equity, dan margin laba bersih secara simultan berpengaruh signifikan terhadap harga saham di bursa Indonesia. Secara parsial, return on asset, return on equity, dan margin laba bersih berpengaruh signifikan terhadap harga saham di bursa Indonesia, tetapi efek dari return on equity terhadap harga saham adalah negatif. Koefisien determinasi menunjukkan adjusted R-square sebesar 0,529, yang berarti bahwa 52,90\% dari harga saham dipengaruhi oleh ROA, ROE dan NPM, dan $47,10 \%$ dari harga saham dipengaruhi oleh variabel lain yang tidak diteliti.
\end{abstract}

Kata Kunci: rasio profitabilitas, go publik, industri perbankan, harga saham, bursa saham Indonesia

\section{PENDAHULUAN}

Dampak krisis global di sektor keuangan telah memengaruhi kondisi perbankan di Indonesia. Salah satu contoh adalah kasus pada Bank Century yang menerima dana talanan dari Bank Indonesia (bailout) sebagai akibat dari tekanan likuiditas sehingga mengalami gagal kliring. Hal ini tentunya sangat berdampak pada kepercayaan publik terutama sekali pada nasabah yang menyimpan uangnya pada Bank Century, meskipun setiap dana yang tersimpan pada bank akan dijamin oleh Lembaga Penjamin Simpanan (LPS), akan tetapi publik khawatir karena tentunya publik tidak ingin menyimpan dananya pada bank yang dipandang kurang sehat karena khawatir terhadap dana yang tersimpan pada bank tersebut.

Kondisi industri perbankan dapat dilihat berdasarkan perkembangan pasar modal. Pasar modal dapat dijadikan indikator karena pasar modal merupakan bagian dari sistem keuangan yang melibatkan sejumlah bank yang merupakan emiten di pasar tersebut. Hal yang dipantau dari pasar modal antara lain adalah nilai transaksi dan volume transaksi, kapitalisasi pasar, jumlah emiten, serta indeks harga saham gabungan (IHSG). 
Undang-Undang No. 8 tahun 1995 tentang pasar modal mendefinisikan pasar modal sebagai kegiatan yang bersangkutan dengan penawaran umum dan perdagangan efek, perusahaan publik yang berkaitan dengan efek yang diterbitkannya, serta lembaga dan profesi yang berkaitan dengan efek. Efek adalah surat berharga yaitu surat pengakuan utang, surat berharga komersial, saham, obligasi, tanda bukti utang. Pasar Modal memiliki peran penting bagi perekonomian suatu negara karena pasar modal menjalankan dua fungsi, yaitu pertama sebagai sarana pendanaan usaha atau sebagai sarana perusahaan untuk mendapatkan dana dari masyarakat pemodal (investor). Dana yang diperoleh dari pasar modal dapat digunakan untuk pengembangan usaha, ekspansi, penambahan modal kerja. Pasar modal juga menjadi sarana bagi masyarakat untuk berinvestasi pada instrumen keuangan seperti saham, obligasi, reksa dana, dan lain-lain.

Masalah yang sering dihadapi oleh investor di pasar modal adalah memilih perusahaan yang tepat untuk melakukan investasi agar diperoleh investasi dengan harga yang wajar dan mencerminkan investasi yang potensial. Untuk itu, bagi para investor yang ingin melakukan investasi pada common stock sebaiknya terlebih dahulu mengidentifikasi surat berharga yang akan diinvestasikan dengan tepat serta mempertimbangkan kondisi dan prospek perusahaan di masa yang akan datang dalam meningkatkan laba perusahaan (Margaretha \& Damayanti, 2008: 150).

Ada beberapa faktor penyebab naik dan turunnya harga saham. Pertama, kenaikan harga saham dapat disebabkan oleh kinerja fundamental perusahaaan terutama kinerja keuangan. Alwi (2003: 87) berpendapat bahwa salah faktor yang memengaruhi pergerakan harga saham adalah pengumuman laporan keuangan perusahaan, seperti peramalan laba sebelum akhir tahun fiskal dan setelah akhir tahun fiskal, earning per share (EPS) dan dividen per share (DPS), price earning ratio (PER), net profit margin (NPM) dan Return on Assets ( ROA).

\section{KAJIAN LITERATURE DAN PENGEMBANGAN HIPOTESIS Perbankan}

Undang-Undang Nomor 10 Tahun 1998 tentang Perubahan Atas Undang-Undang Nomor 7 Tahun 1992 tentang perbankan mendefinisikan bank sebagai badan usaha yang menghimpun dana dari masyarakatdalam bentuk simpanan dan menyalurkannya kepada masyarakatdalam bentuk kredit dan

Menurut Kasmir (2008:11) secara umum bank diartikan sebagai lembaga keuangan yang kegiatan usahanya adalah menghimpun dana dari masyarakat dan menyalurkan kembali dana tersebut ke masyarakat serta memberikan jasa-jasa bank lainnya. Sementara Malayu (2004:2) menyatakan bank adalah lembaga keuangan, berarti bank adalah badan usaha yang kekayaannya terutama dalam bentuk aset keuangan (financial assets) serta bermotifkan profit dan juga sosial, jadi bukan hanya mencari keuntungan semata.

Jenis-jenis bank sebagaimana yang diatur dalam Undang-Undang Nomor 10 Tahun 1998, terdiri dari:

1. Bank Umum adalah bank yang melaksanakan kegiatan usaha secara konvensional dan atau berdasarkan prinsip syariah yang dalam kegiatannya memberikan jasa dalam lalu lintas pembayaran.

2. Bank Perkreditan Rakyat adalah bank yang melaksanakan kegiatan usaha secara konvensional atau berdasarkan prinsip syariah yang dalam kegiatannya tidak memberikan jasa dalam lalu lintas pembayaran

Kasmir (2008:27) membagi empat jenis bank berdasarkan kepemilikannya yaitu:

1. Bank Milik Pemerintah, merupakan bank yang dimiliki oleh pemerintah, baik akta pendirian, modal dan seluruh keuntungannya.

2. Bank Milik Swasta Nasional, merupakan bank yang dimiliki oleh swasta nasional baik akta pendirian, modal dan seluruh keuntungannya. 
3. Bank Milik Asing, merupakan cabang dari bank yang ada di luar negeri. Cabang tersebut dapat merupakan milik swasta asing maupun pemerintah asing suatu Negara.

4. Bank Milik Campuran, merupakan bank yang kepemilikan sahamnya dimiliki oleh pihak asing dan pihak swasta nasional.

\section{Kinerja Keuangan}

Kinerja keuangan seringkali dikaitkan dengan kondisi keuangan perusahaan. Untuk mengetahui kondisi keuangan suatu perusahaan termasuk perusahaan perbankan pada umumnya berfokus pada laporan keuangan di samping data-data non keuangan lainnya yang bersifat sebagai penunjang.Informasi yang terkandung dalam laporan keuangan digunakan investor untuk memperkirakan tentang laba dan deviden di masa mendatang dan risiko atas penilaian tersebut ( Brigham dan Houston, 2006).

Fahmi (2011:2) mengemukakan bahwa kinerja keuangan adalah suatu analisis yang dilakukan untuk melihat sejauh mana suatu perusahaan telah melaksanakan dengan menggunakan aturan-aturan pelaksanaan keuangan secara baik dan benar. Kinerja perusahaan merupakan suatu gambaran tentang kondisi keuangan suatu perusahaan yang dianalisis dengan alat-alat analisis keuangan, sehingga dapat diketahui mengenai baik buruknya keadaan keuangan suatu perusahaan yang mencerminkan prestasi kerja dalam periode tertentu.

Sementara Mulyadi (2001:178) berpendapat bahwa kinerja keuangan adalah suatu tampilan tentang kondisi keuangan perusahaan selama periode tertentu. Untuk mengukur keberhasilan suatu perusahaan pada umumnya berfokus pada laporan keungannya di samping data-data non keuangan lain yang bersifat sebagai penunjang. Informasi kinerja bermanfaat untuk memprediksi kapasitas perusahaan dalam menghasilkan arus kas dari sumber dana yang ada.

\section{Rasio Keuangan Bank}

Rasio keuangan adalah hasil perhitungan antara dua macam data keuangan bank, yang digunakan untuk menjelaskan hubungan antara kedua data keuangan tersebut yang pada umumnya dinyatakan secara numerik, baik dalam persentase atau kali. Masing-masing rasio harus memiliki tujuan sehingga tidak akan ditemukan batasan yang jelas dan tegas berapa rasio yang terdapat pada setiap aspek yang dianalisis (Riyadi, 2003:124).

Kasmir (2008:122) mengemukakan bahwa rasio keuangan merupakan perbandingan angkaangka dalam laporan keuangan dengan melakukan perbandingan antar komponennya sehingga menjadi angka dalam satu periode atau beberapa periode.

Munawir (2006:6) menyatakan bahwa terdapat teknik analisis laporan keuangan yang biasa digunakan, antara lain:

1. Analisis perbandingan laporan keuangan.

2. Analisis trend (Trend Percentage Analysis).

3. Laporan dengan prosentase per komponen (Commonsize Statement).

4. Analisis sumber dan penggunaan modal kerja.

5. Analisis sumber dan penggunaan kas (Cash Flow Statement Analysis).

6. Analisis rasio.

7. Analisis perubahan laba kotor (Gross Profit Analysis).

8. Analisis Break-Even.

Analisa laporan keuangan yang meliputi perhitungan dan interpretasi rasio sangat diperlukan untuk dapat memahami informasi tentang laporan keuangan. Rasio keuangan yang umum untuk mengukur kinerja perbankan adalah (1) rasio rentabilitas dengan pendekatan ROA (Return on Assets), ROE (Return on Equity), (2) rasio solvabilitas yang dapat dengan pendekatan Capital Ratio dan (3) rasio 
likuiditas yang diukur dengan pendekatan Loan to Deposit Ratio. Selain itu rasio Earning per Share digunakan oleh investor sebagai alat untuk menganalisis kemampuan perusahaan dalam mencetak laba berdasarkan saham yang dimiliki. Hal ini menunjukkan bahwa rasio keuangan bermanfaat dalam menilai kondisi keuangan perbankan (Utami, 2005:110).

\section{Return on Assets ( ROA )}

Sutrisno (2009:222), mengemukakan bahwa return on assets juga disebut sebagai rentabilitas ekonomis merupakan ukuran kemampuan perusahaan dengan menghasilkan laba dengan semua aktiva yang dimiliki oleh perusahaan. Dalam hal ini laba yang dihasilkan adalah laba sebelum bunga dan pajak. Rasio ini digunakan untuk mengukur kemampuan manajemen perusahaan dalam memperoleh keuntungan (laba) secara keseluruhan. Rasio ini menunjukkan tingkat efisiensi pengelolaan aktiva yang dilakukan oleh perusahaan. Semakin besar ROA maka semakin besar tingkat keuntungan dan semakin baik posisi perusahaan dari segi penggunaan aktiva. Syamsuddin (2009:40) merumuskan formula untuk menghitung pengembalian tingkat aktiva/return on asset (ROA) sebagai berikut:

$$
\text { Return On Asset }=\frac{\text { Laba Setelah Pajak }}{\text { Aktiva }}
$$

\section{Return on Equity ( ROE )}

Rasio ini menunjukkan kemampuan modal pemilik yang ditanamkan oleh pemilik atau investor untuk menghasilkan laba bersih yang menjadi bagian dari pemilik. Semakin tinggi rasio ini semakin tinggi keuntungan investor karena semakin efisien modal yang ditanamkannya. Dengan demikian, rasio ini sangat mendapat perhatian para investor.

Rasio ini untuk mengukur laba bersih sesudah pajak dengan modal sendiri. Rasio ini menunjukkan efisiensi penggunaan modal sendiri. Semakin tinggi rasio ini, semakin baik (Kasmir, 2012:204) . Rasio diperoleh dengan menggunakan rumus:

$$
\text { Return On Equity }=\frac{\text { Earning After Interest and Tax }}{\text { Equity }}
$$

\section{Net Profit Margin ( NPM )}

Net Profit Margin merupakan salah satu jenis ratio profitabilitas untuk menilai serta mengukur posisi keuangan perusahaan dalam suatu periode tertentu atau untuk beberapa periode. Cara pengukuran rasio ini adalah membandingkan laba bersih setelah pajak dengan penjualan bersih.

Kasmir (2012:235) mengemukakan bahwa rasio ini digunakan untuk mengukur kemampuan bank dalam menghasilkan net income dari kegiatan operasi pokoknya. Nilai NPM diperoleh dengan menggunakan rumus:

$$
\text { Return On Asset }=\frac{\text { Net Income }}{\text { Operating Income }}
$$

\section{Saham}

Sekuritas (saham) merupakan secarik kertas yang menunjukkan hak pemodal (yaitu pihak yang memiliki kertas tersebut) untuk memperoleh bagian dari prospek atau kekayaan organisasi yang menerbitkan sekuritas tersebut dan berbagai kondisi yang memungkinkan pemodal tersebut menjalankan haknya (Husnan, 2002:303).

Darmadji dan Fakhrudin (2006:5) berpendapat bahwa saham (stock atau share) adalah tanda penyertaan atau pemilikan seseorang atau badan dalam suatu perusahaan atau perseroan terbatas. Sementara Kismono (2001:416) menyatakan bahwa saham merupakan sebuah piagam yang berisi aspek-aspek penting bagi perusahaan, termasuk hak dari pemilik saham dan hak khusus yang 
dimilikinya berkaitan dengan kepemilikan saham. Contohnya adalah hak mendapatkan pendapatan tetap dari perusahaan di samping punya kewajiban untuk ikut menanggung risiko bila perusahaan dilikuidasi. Pemilik saham juga berhak mengontrol perusahaan sesuai dengan kapasitas ( jumlah ) saham yang dimilikinya melalui rapat umum pemegang saham dengan menggunakan hak suara yang dimilikinya.

Menurut Darmadji dan Hendi (2006:6) saham dapat dikelompokkan dalam tiga kategori berdasarkan hak tagih, peralihan hak, dan kinerja, yaitu:

1. Berdasarkan hak tagih atau klaim

a. Saham Biasa (Common Stock), adalah jenis saham yang memiliki hak klaim berdasar laba/rugi yang diperoleh perusahaan.

b. Saham preferen (Prefered Stock), merupakan saham yang memiliki karakteristik gabungan antar obligasi dan saham biasa, karena bisa menghasilkan pendapatan tetap (seperti bunga obligasi), tetapi juga bisa tidak mendatangkan hasil seperti yang dikehendaki.

2. Berdasarkan Peralihan hak

a. Saham atas Unjuk (Bearer stock), merupakan jenis saham yang memiliki karakteristik tidak tercantum nama pemilik dengan tujuan agar saham tersebut dapat dengan mudah dipindah tangankan dari suatu investor ke investor lainnya.

b. Saham atas nama (Registered Stock), mencantumkan nama dari pemilik saham pada lembar saham.

3. Berdasarkan kinerja saham

a. Blue Chip Stock, yaitu saham biasa dari suatu perusahaan yang memiliki reputasi tinggi sebagai leader di industri sejenis, memiliki pendapatan yang stabil dan konsisten dalam membayar deviden.

b. Income Stock, yaitu saham dari suatu emiten yang memiliki kemampuan membayar deviden lebih tinggi dari rata-rata deviden yang dibayarkan pada tahun sebelumnya.

c. Growth Stock, merupakan saham-saham dari emiten yang memiliki pertumbuhan pendapatan yang tinggi, sebagai leader di industri sejenis yang mempunyai reputasi tinggi.

d. Speculative Stock, adalah saham suatu perusahaan yang tidak bisa secara konsisten memperoleh penghasilan dari tahun ke tahun, akan tetapi mempunyai kemungkinan penghasilan yang tinggi di masa mendatang meskipun belum pasti.

e. Counter Cyclical Stock, merupakan saham yang tidak terpengaruh oleh kondisi ekonomi makro maupun situasi bisnis secara umum.

Harga saham adalah harga suatu saham yang terjadi di pasar bursa pada saat tertentu yang ditentukan oleh pelaku pasar dan ditentukan oleh permintaan dan penawaran saham yang bersangkutan di pasar modal (Jogiyanto, 2008:167).

Menurut Anoraga (2006: 100) harga saham adalah uang yang dikeluarkan untuk memperoleh bukti penyertaan atau pemilikan suatu perusahaan. Harga saham juga dapat diartikan sebagai harga yang dibentuk dari interaksi para penjual dan pembeli saham yang dilatarbelakangi oleh harapan mereka terhadap profit perusahaan, untuk itu investor memerlukan informasi yang berkaitan dengan pembentukan saham tersebut dalam mengambil keputusan untuk menjual atau membeli saham.

Menurut Widiatmojo (2001:45), harga saham dapat dibedakan menjadi beberapa jenis yaitu:

1) Harga Nominal, yaitu nilai yang ditetapkan oleh emiten untuk menilai setiap lembar saham yang dikeluarkannya.

2) Harga Perdana, yaitu harga sebelum harga tersebut dicatat di bursa efek.

3) Harga Pasar, yaitu harga jual dari investor yang satu ke investor yang lain.

4) Harga Pembukaan, yaitu harga yang diminta penjual dari pembeli pada saat jam bursa dibuka.

5) Harga Penutupan, yaitu harga yang diminta oleh penjual dan pembeli saat akhir hari buka. 
6) Harga Tertinggi. Harga saham tidak hanya sekali atau dua kali dalam satu hari, tetapi bisa berkali dan tidak terjadi pada harga saham yang lama.

7) Harga Terendah, yaitu harga yang paling rendah pada satu hari bursa.

8) Harga Rata-rata, merupakan rata-rata dari harga tertinggi dan terendah.

Untuk menentukan harga saham terdapat dua pendekatan, yaitu analisis fundamental dan analisis teknikal (Ghozali dan Sugiyanto, 2002: 91-96).

1. Analisis Fundamental

Analisis fundamental merupakan salah satu cara yang lazim digunakan oleh para pemodal untuk menilai saham. Analisis fundamental memiliki asumsi dasar bahwa harga saham tidaklah diukur dari standar harga di pasar, melainkan diprediksikan terlebih dahulu dengan analisis perusahaan (Husnan, 2002:336).

2. Analisis Teknikal

Analisis teknikal didahului dengan asumsi dasar bahwa harga sahamterbentuk dari hasil spekulasi.Kegiatanspekulasi tersebut menitik beratkan pada trend yang dibentuk harga sahampada periode yang lalu dan tidak ada hubungannya dengan nilai intrinsik saham.Kenaikan dan penurunan harga saham pada periode sebelumnyadigunakan untuk memprediksi harga saham pada periode berikutnya.Trend harga saham menjadi tolok ukur untuk memprediksi harga sahamperiode berikutnya.

\section{METODE PENELITIAN}

Jenis penelitian yang digunakan dalam penelitian ini adalah deskriptif dengan pendekatan kuantitatif.Artinya, analisis dalam penelitian ini ditekankan pada hasil pengolahan data-data numeric ( angka ).

Menurut Sugiyono (2013: 53) metode deskriptif adalah penelitian yang dilakukan untuk mengetahui keberadaan variabel mandiri, baik hanya pada satu variabel atau lebih. Sementara jenis penelitian kuantitatif dapat diartikan sebagai metode penelitian yang berlandaskan pada filsafat positivisme, digunakan untuk meneliti pada populasi atau sampel tertentu.

Teknik sampling yang digunakan dalam penelitian ini adalah Nonprobability Sampling yaitu Sampling Jenuh. Menurut Sugiyono (2013:85), sampling jenuh adalah teknik penentuan sampel bila semua anggota populasi digunakan sebagai sampel. Dalam penelitian ini yang menjadi sampel adalah 30 perusahaan perbankan yang listing di Bursa Efek Indonesia. Sementara alat analisis yang digunakan dalam penelitian ini adalah multiple regression atau regresi linear berganda.

\section{HASIL DAN PEMBAHASAN}

Regresi Linear Berganda merupakan salah satu alat Statistik Parametrik Regresi Linear Berganda dengan fungsi menganalisis dan menerangkan pengaruh variabel Return on Assets ( ROA ) $\left(\mathrm{X}_{1}\right)$, Return on Equity (ROE) $\left(\mathrm{X}_{2}\right)$ dan Net Profit Margin (NPM) $\left(\mathrm{X}_{3}\right)$ terhadap harga saham (Y) di Bursa Efek Indonesia (BEI).

Berdasarkan hasil analisis regresi linear berganda diperoleh hasil-hasil penelitian dari 30 industri perbankan dengan yang dirumuskan model persamaan regresi berganda sebagai berikut:

$$
Y=-616,836+1857,093 X 1-139,727 X 1+95,794 X 2
$$

Persamaan regresi tersebut dapat dijelaskan sebagai berikut:

1. Nilai konstanta sebesar $-616,836$ dan bernilai negatif, hal ini menunjukkan bahwa harga saham industri perbankan di Bursa Efek Indonesia (BEI) sebelum adanya variabel ROA, ROE dan NPM sebesar $-616,836$. 
2. Return on As ( ROA) dengan koefisien regresi sebesar 1857,093. Hal ini menunjukkan bahwa adanya pengaruh yang positif antara ROA dengan harga saham industri perbankan di Bursa Efek Indonesia (BEI). Koefisien ini mengandung arti bahwa apabila ROA mengalami peningkatan sebesar 1 (satu) satuan maka harga saham akan mengalami peningkatan sebesar 1857,093.

3. Return on Equity (ROE) dengan koefisien regresi sebesar -139,727 . Hal ini menunjukkan bahwa adanya pengaruh yang negatif antara ROE dengan harga saham industri perbankan di Bursa Efek Indonesia (BEI). Koefisien ini mengandung arti bahwa apabila ROE mengalami peningkatan sebesar 1 (satu) satuan maka harga saham akan turun sebesar -139,727.

4. Net Profit Margin (NPM) dengan koefisien regresi sebesar 95,794. Hal ini menunjukkan bahwa adanya pengaruh yang positif antara NPM dengan harga saham industri perbankan di Bursa Efek Indonesia (BEI). Koefisien ini mengandung arti bahwa apabila NPM mengalami peningkatan sebesar 1 (satu) satuan maka harga saham akan mengalami peningkatan sebesar 95,794.

\section{Hipotesis}

\section{Uji Simultan (Uji F)}

Hasil uji determinasi (kehandalan model) diperoleh nilai Adjusted $R$-Square sebesar 0,529 atau sebesar 52,90\% harga saham dipengaruhi oleh ROA, ROE dan NPM. Sedangkan selebihnya sebesar 47,10\% harga saham dipengaruhi oleh variabel lain yang tidak diteliti dalam penelitian ini.

Selanjutnya dari hasil pengujian ANOVA diperoleh $\mathrm{F}_{\text {hitung }}$ sebesar 34.332 pada taraf nyata $\alpha$ sebesar 0,05 atau sig. $\mathrm{F}<0,05$, dengan nilai signifikansi $\mathrm{F}$ sebesar 0,000 . Sehingga dengan demikian dapat dinyatakan bahwa secara bersama-sama variabel bebas yang terdiri dari Return on Assets (ROA), Return on Equity (ROE) dan Net Profit Margin ( NPM) mempunyai pengaruh yang signifikan terhadap harga saham pada industri perbankan di Bursa Efek Indonesia.

Hasil membuktikan bahwa hipotesis pertama yang menyatakan bahwa: "Return on Assets, Return on Equity, dan Net Profit Margin secara simultan berpengaruh signifikan terhadap harga saham pada industri perbankan yang go public di Bursa Efek Indonesia" ternyata terbukti.

\section{Uji Parsial (Uji t)}

a. Pada variabel return on assets (ROA), hasil perhitungan menunjukkan bahwa nilai koefisien regresi sebesar 1857,093 sementara tingkat signifikansi sebesar 0,000 dengan nilai signifikansi $\mathrm{t}$ $<0,05$ pada taraf kepercayaan 95\%. Dengan demikian dapat dinyatakan bahwa variabel return on assets mempunyai pengaruh yang signifikan terhadap harga saham pada industri perbankan yang go public di Bursa Efek Indonesia. Hasil tersebut membuktikan bahwa hipotesis kedua yang menyatakan "return on assets secara parsial berpengaruh signifikan terhadap harga saham pada industri perbankan yang go public di Bursa Efek Indonesia", adalah terbukti.

b. Pada variabel return on equity (ROE), hasil perhitungan menunjukkan bahwa nilai koefisien regresi sebesar $-139,727$, sementara tingkat signifikansi sebesar 0,000 dengan nilai signifikansi t $<0,05$ pada taraf kepercayaan 95\%. Dengan demikian dapat dinyatakan bahwa variabel return on equity mempunyai pengaruh yang signifikan terhadap harga saham pada industri perbankan yang go public di Bursa Efek Indonesia.Hasil tersebut membuktikanbahwa hipotesis ketiga yang menyatakan "return on equity secara parsial berpengaruh signifikan terhadap harga saham pada industri perbankan yang go public di Bursa Efek Indonesia", adalah terbukti.

c. Pada variabel net profit margin (NPM), hasil perhitungannya menunjukkan bahwa nilai koefisien regresi sebesar 95,794, sementara tingkat signifikansi sebesar 0,010 dengan nilai signifikansi $\mathrm{t}<$ 0,05 pada taraf kepercayaan 95\%. Dengan demikian dapat dinyatakan bahwa variabel net profit margin mempunyai pengaruh yang signifikan terhadap harga saham pada industri perbankan yang go public di Bursa Efek Indonesia.Hasil tersebut membuktikan bahwa hipotesis keempat 
yang menyatakan "net profit margin secara parsial berpengaruh signifikan terhadap harga saham pada industri perbankan yang go public di Bursa Efek Indonesia”, adalah terbukti.

\section{Pengaruh Return on Assets ( ROA) Terhadap Harga Saham}

ROA menggambarkan kemampuan perusahaan untuk menghasilkan keuntungan dari setiap satu rupiah asset yang digunakan. Dengan ini bisa dinilai apakah perusahaan ini efisien memanfaatkan aktivitasnya dalam kegiatan operasional perusahaan. ROA juga memberikan ukuran yang lebih baik atas profitabilitas perusahaan karena menunjukkan efiktivitas manajemen dalam menggunakan aktiva untuk memperoleh pendapatan.

Hasil penelitian juga menunjukkan bahwa ROA merupakan variabel paling berpengaruh terhadap harga saham. Kondisi ini tentunya membawa dampak pada peningkatan citra perbankan bagi investor, sehingga semakin banyak investor yang menjadi tertarik untuk menanamkan modalnya karena tertarik dengan tingkat pengembalian akan semakin besar. Dengan ketertarikan investor tersebut tentunya juga akan berdampak pada harga saham perbankan yang diperjual belikan di Bursa Efek Indonesia karena permintaan terhadap saham perbankan semakin besar dibandingkan dengan jumlah saham yang ditawarkan. Dengan demikian dapat dikatakan bahwa dengan semakin tingginya ROA maka tinggi pula tingkat keuntungan yang dicapai yang pada akhirnya akan meningkatkan pula harga saham.

Para pemegang saham menaruh perhatian utama pada tingkat keuntungan baik sekarang maupun masa yang akan datang karena tingkat keuntungan ini akan memengaruhi harga saham-saham yang mereka miliki. Jadi, dengan berarti meningkatkan harga saham secara tidak langsung akan meningkatkan pendapatan per lembar saham (Syamsuddin, 2004:63).

\section{Pengaruh Return on Equity ( ROE) Terhadap Harga Saham}

Pengaruh ROE terhadap harga saham tersebut disebabkan karena nilai signifikansinya lebih kecil dari 0,05 yaitu sebesar 0,010 . Kondisi ini tentunya bertentangan dengan teori yang menyatakan bahwa semakin tinggi ROE berarti semakin baik kinerja perusahaan dalam mengelola modalnya untuk menghasilkan keuntungan bagi pemegang saham. Rasio ROE yang tinggi cenderung meningkatkan minat investor terhadap saham karena menganggap perusahaan tersebut mempunyai prospek yang baik dalam meningkatkan laba.

ROE merupakanrasio penting bagi para pemilik dan pemegang saham karena rasio tersebut menunjukkan kemampuan perusahaan dalam mengelola modal dari pemegang saham untuk mendapatkan laba bersih. Perusahaan yang memiliki Return onEquity yang rendah atau bahkan negatif akan terklasifikasikan sebagai perusahaan yang kurang baik dalam menghasilkan laba yang menjadi hak pemegang saham.

ROE merupakan suatu pengukuran dari penghasilan (income) yang tersedia bagi para pemilik perusahaan (baik pemegang saham biasa maupun pemegang saham preferen) atas modal yang mereka investasikan di dalam perusahaan. Secara umum tentu saja semakin tinggi return atau penghasilan yang diperoleh semakin baik kedudukan pemilik perusahaan (Syamsuddin, 2009:64).

\section{Pengaruh Net Profit Margin ( NPM) Terhadap Harga Saham}

Hasil tersebut mengindikasikan bahwa NPM yang dihasilkan berpengaruh signifikan terhadap harga saham pada industri perbankan yang go public di Bursa Efek Indonesia. Hal ini sejalan dengan teori yang mendasarinya bahwa NPM menunjukkan tingkat pengembalian keuntungan bersih terhadap penjualan bersihnya dan sekaligus menunjukkan efisiensi biaya yang dikeluarkan perusahaan, sehingga apabila NPM semakin besar atau mendekati satu, maka berarti semakin efisien biaya yang dikeluarkan sehingga semakin besar tingkat kembalian keuntungan bersih, semakin meningkatnya NPM. Dengan semakin meningkatnya NPM tentunya akan meningkatkan kepercayaan investor untuk menanamkan modalnya pada perusahaan tersebut sehingga dengan demikian akan meningkatkan 
permintaan akan saham perusahaan tersebut yang pada akhirnya akan diikuti dengan naiknya harga saham perusahaan.

Net Profit Margin adalah perbandingan antara laba bersih dengan penjualan bersih. Semakin besar NPM menunjukan kinerja perusahaan yang produktif untuk memperoleh laba yang tinggi melalui tingkat penjualan tertentu serta kemampuan perusahaan yang baik dalam menekan biayabiaya oprasionalnya. Hal ini meningkatkan kepercayaan investor untuk menginvestasikan modalnya pada perusahaan tersebut sehingga permintaan akan saham perusahaan meningkat yang otomatis akan diikuti peningkatan harga saham tersebut (Bastian dan Suhardjono, 2006:299).

\section{KESIMPULAN DAN SARAN}

\section{Kesimpulan}

Berdasarkan hasil penelitian dan pembahasan, maka dapat diambil kesimpulan sebagai berikut:

1. Return on assets, return on equity, dan net profit margin, secara simultan berpengaruh signifikan terhadap harga saham pada industri perbankan yang go public di Bursa Efek Indonesia.

2. Return on assets secara parsial berpengaruh signifikan terhadap harga saham pada industri perbankan yang go public di Bursa Efek Indonesia.

3. Return on equity secara parsial berpengaruh signifikan terhadap harga saham pada industri perbankan yang go public di Bursa Efek Indonesia.

4. Net profit margin secara parsial berpengaruh signifikan terhadap harga saham pada industri perbankan yang go public di Bursa Efek Indonesia.

\section{Saran}

1. Sebaiknya para investor mempertimbangkan faktor-faktor lain yang berpengaruh terhadap harga saham sehingga dalam pengambilan keputusan untuk menanamkan modal dapat lebih akurat dan resiko terhadap modal yang ditanam yang terjadi dapat diminimalisir. Selain itu investor juga jangan terpaku pada tingkat keuntungan sesaat yang diberikan oleh perbankan tetapi lebih pada faktor-faktor yang berpengaruh di masa depan.

2. Untuk pihak manajemen hendaknya lebih memperhatikan apa yang menjadi motivasi dari investor dalam menanamkan modalnya. Hal tersebut dapat menjadi referensi bagi pihak manajemen untuk mengambil langkah-langkah strategis untuk menarik para investor dalam menanamkan modalnya.

3. Bagi peneliti lain yang akan meneliti tentang harga saham perbankan diharapkan dapat menggunakan rasio-rasio keuangan lain yang dapat memengaruhi saham perbankan.

\section{REFERENSI}

Alwi, Z. I.. (2003). Pasar Modal Teori dan Aplikasi Edisi Pertama, Penerbit Yayasan Pancur Siwah, Jakarta

Anoraga, P. dan Pakarti, (2006). Pengantar Pasar Modal, Cetakan Pertama, Jakarta: PT. Rineka Cipta.

Brigham, Eugene F dan Joel Houston. (2006). Dasar-Dasar Manajemen Keuangan (Edisi Kesepuluh), Jakarta: Salemba Empat.

Darmadji, Tjiptono. dan Fakhruddin, H. M. (2006). Pasar modal di indonesia. (Edisi 2). Jakarta: Penerbit Salemba Empat

Fahmi, Irham. (2011). Analisis Kinerja Keuangan, Cetakan Kesatu, Bandung: Penerbit Alfabeta

Ghozali, Imam. (2006). Aplikasi Analisis Multivarite dengan SPSS, Cetakan Keempat. Semarang: Badan Penerbit Universitas Diponegoro. 
Husnan, Suad. (2002). Dasar-dasar Teori Portofolio dan Analisis Sekuritas. Edisi ketiga.Yogyakarta : AMP YKPN.

Jogiyanto, HM. (2008). Teori Portofolio Dan Analisis Investasia. Yogyakarta: BPFE.

Kasmir. (2008). Bank dan Lembaga Keuangan Lainnya. Edisi Revisi. Jakarta: PT Rajagrafindo Persada.

Kasmir. (2012). Analisis Laporan Keuangan. Jakarta. PT. Rajagrafindo Persada.

Kismono, Gugup. (2001). Pengantar Bisnis. Yogyakarta: BPFE

Margaretha, Farah dan Irma Damayanti. (2008). Pengaruh Price Earnings Ratio, Dividend Yield Dan

Market To Book Ratio Terhadap Stock Return Di Bursa Efek Indonesia. Jurnal Bisnis Dan Akuntansi. Vol. 10, No. 3

Mulyadi. (2001). Balanced Scorecard: Alat Manajemen Kontemporer Untuk Pelipatganda Kinerja Keuangan Perusahaan. Jakarta: Salemba Empat.

Riyadi, Selamet. 2003. Banking Asset and Liabillity Management. Jakarta: Penerbit Fakultas Ekonomi Universitas Indonesia.

Sugiyono. (2009). Metodologi Penelitian Kuantitatif, Kualitatif, dan R\&D. Bandung: Alfabeta.

Sutrisno. (2009). Manajemen Keuangan Teori Konsep dan Aplikasi, Cetakan Ketujuh. Yogyakarta: Ekoisia.

Syamsuddin, Lukman. (2009). Manajemen Keuangan Perusahaan. Jakarta: PT. Raja Grafindo Persada.

Undang-Undang Republik Indonesia Nomor 10 Tahun 1998 tentang Perubahan Atas Undang-Undang Republik Indonesia Nomor 7 Tahun 1992 tentang perbankan. Jakarta

Undang-Undang Republik Indonesia No. 8 tahun 1995 tentang Pasar Modal. Jakarta

Utami, Setyaningsih Sri. (2005). Pengaruh Rasio Keuangan Terhadap Harga Saham (Studi pada Perusahaan Perbankan di Bursa Efek Jakarta).Jurnal Ekonomi dan Kewirausahaan. Vol. 5, No.

2 , hal. $110-122$ 